BARBARA LENA GIERSZEWSKA

Instytut Filologii Polskiej

Uniwersytet Jana Kochanowskiego w Kielcach
Images

vol. XXVII/no. 36

Poznań 2020

ISSN 1731-45Ox

\title{
„Nie zapomnij mnie”. O filmowo-ekonomicznej przestrzeni w dziejowości Wrocławia 1896-1945
}

\begin{abstract}
AвstraCt. Gierszewska Barbara Lena, „Nie zapomnij mnie”. O filmowo-ekonomicznej przestrzeni w dziejowości Wrocławia 1896-1945 [„„Do not forget me”. About film-economic space in the history of Wrocław 1896-1945]; review of Andrzej Dębski’s book Nowoczesność, rozrywka, propaganda. Historia kina we Wrocławiu w latach 1919-1945. "Images" vol. XXVII, no. 36. Poznań 2020. Adam Mickiewicz University Press. Pp. 247-258. ISSN 1731-450X. DOI 10.14746/i.2020.36.16.

The author of the reviewed book for the first time shows how and why film preferences of the inhabitants of Breslau in the years 1896-1932 and 1933-1945 differed in relation to the choices of cinema audiences in other European cities during the same period. He uses the POPSTAT statistical method proposed for this purpose by the German researcher Joseph Potter. He also uses the scientific ideas of „attraction cinema” developed by André Gaudreault. He bases his research on analyzing film success rankings and to measure viewer preferences.
\end{abstract}

KEYwORDS: Wrocław, Lower Silesian Voivodeship, cinematography, cinema, free time, entertainment, participation in culture, media history

\section{Recenzja}

Andrzej Dębski, Nowoczesność, rozrywka, propaganda. Historia kina we Wrocławiu w latach 1919-1945, Wrocław, ATUT 2019, cz. I i cz. II

Książka Andrzeja Dębskiego Nowoczesność, rozrywka, propaganda. Historia kina we Wrocławiu w latach 1919-1945 wpisuje się w nurt opracowań naukowych kulturoznawców poświęconych poszczególnym miastom i regionom Europy z okresu przełomu XIX i XX wieku oraz dwudziestolecia międzywojennego i okresu II wojny światowej, którzy sytuują ówczesne praktyki filmowe w perspektywie „kina atrakcji” i zjawisk, które w obiegu naukowym zostały opisane między innymi przez Edgara Morina[1] i Antoninę Kłoskowską[2], by wymienić tych najwcześniejszych i najbardziej u nas popularnych. Obecnie, po kilku dekadach prymatu w naukowym dyskursie badań nad kulturą filmową wczesnej kinematografii, nastąpił zwrot w kierunku namysłu nad repertuarem i frekwencyjnością kin, potwierdzając i znacząco rozwijając wczesną tezę postrzegania filmu jako narzędzia rozrywki jednostek i grup społeczności miejskich w pierwszej, drugiej i trzeciej dekadzie XX stulecia.

[1] E. Morin, Kino i wyobraźnia, Warszawa 1958; idem, Duch czasu, Warszawa 1965.
[2] A. Kłoskowska, Kultura masowa, Warszawa 1964. 
Książka została opracowana w konwencji historyczno-socjologicznej (część I: Kina) i ekonomicznej (część II: W kinach) z mocnymi akcentami politycznymi. Otwiera ją spektakularny w przesłaniu do mieszkańców Breslau i Niemców (oraz wrocławian i Polaków jak najbardziej też) aforyzm Arthura Schopenhauera na temat dumy narodowej[3]. Mamy do czynienia z bardzo szczegółową monografią dokumentalno-krytyczną dotyczącą życia filmowego w europejskim mieście do $1945 \mathrm{roku}$, co nie jest częstym zjawiskiem, wręcz przeciwnie, to zdarzenie wyjątkowe. Takie ujęcie tematu przeważnie sprzyja uporządkowaniu materiału i problematyzacji treści, co i w tym przypadku okazało się właściwym wyborem. Autor koncentruje się na dwóch wyżej wymienionych obszarach badawczych, co nie oznacza jednak, iż pominął inne, newralgiczne dla dziejów wrocławskich kin wątki. Interesują go zwłaszcza dwa aspekty: historia założeń kinowych i uwarunkowania rozwoju sieci kin oraz zagadnienie recepcji widowiska filmowego. Problemy te przybliża przez pryzmat dokumentów archiwalnych i materiałów prasowych, dołączając dygresje, komentarze i uzupełnienia autorskie. Stosunkowo mało miejsca poświęcił Dębski kulturze filmowej oraz związkom artystów i twórców filmowych z tym miastem. Pominął - o czym zresztą sam informuje we wstępie - film jako przekaz informacyjny i edukacyjny oraz dorobek filmowy wrocławian i powstały we Wrocławiu. Nie zagłębił się też w rozważania nad myślą i krytyką filmową uprawianą (być może?) przez miejscowych autorów, czy opiniujących wybrane filmy w miejscowej prasie, które to pola potraktował jako służebne otoczenie własnych priorytetów badawczych[4].

Jako autor Andrzej Dębski nie miał łatwego zadania. Z powodu sytuacji geopolitycznej Wrocław był przez wiele lat jakby w letargu, jeśli chodzi o badania nad życiem codziennym i kulturowym do 1945 roku. Niemcy długo nie byli gotowi na zaangażowanie się w naukowe projekty dotyczące miasta (oderwanego od macierzy bezpowrotnie), z kolei Polacy woleli pisać o kresach wschodnich niż poznawać niemiecką spuściznę Wrocławia (chociaż stał się polski). Dębski jako pierwszy opracował dzieje wrocławskich kin epoki wilhelmińskiej, a teraz dzięki kontynuacji znacząco poszerzonych i uzupełnionych badań źródłowych i kwerendzie niemieckich gazet i czasopism oraz innych materiałów drukowanych, przygotował tak imponujące dzieło, które mam zaszczyt recenzować.

Już z powodu ogromu pomieszczonego w niej materiału jest to publikacja niezwykła. Otrzymała też klasyczną szatę graficzną, jaką

[3] Cytat pochodzi z przekładu ostatniego dzieła A. Schopenhauera W poszukiwaniu mądrości życia, które zawiera przyczynki i uzupełnienia do jego fundamentalnej pracy Świat jako wola i przedstawienie. Polski przekład został zatytułowany: W poszukiwaniu mądrości życia. Parerga i paralipomena, t. 1, Warszawa 2002.
[4] Powodem mógł być brak miejsca w książce - autor był skoncentrowany na innych problemach wrocławskiego kina, albo dostosował się do postulatów J. Garncarza, ażeby „zaniechać wartościowania w tym [znaczy: kulturowym] paradygmacie”. A. Dębski, Nowoczesność, cz. 1, s. 18. 
cechują wszystkie prace wydane nakładem Centrum Studiów Niemieckich i Europejskich im. Willy'ego Brandta Uniwersytetu Wrocławskiego w ramach serii „Niemcy - Media - Kultura”. Otrzymaliśmy więc dwa tomy materiałów pełnych faktów, ciekawostek, tropów, śladów, które odkrył Dębski w niemieckich archiwach, bibliotekach, muzeach, wyszperał w niemieckojęzycznych gazetach i czasopismach, afiszach, wspomnieniach oraz przed-i powojennych opracowaniach, nie wspominając o wszelkich innych tekstach niemieckich i polskich uwzględniających interesujące autora wątki. Zgromadzona przez Dębskiego baza dokumentacyjna, na podstawie której przygotował kompendium, może budzić tylko uznanie i respekt dla jego zapału, pracowitości, dociekliwości, wytrwałości, ale przede wszystkim inteligencji, rzetelnej wiedzy, kreatywności i talentu pisarskiego. Tak więc, można nie podzielać entuzjazmu autora co do przełomowości efektów w badaniach nad popularnością filmów i frekwencyjnością wrocławskich kin dzięki zastosowaniu metody Sedgwicka i metody Garncarza („Świadomość istotności tego typu badań miała wpływ na moje wybory w zakresie problematyki drugiej części książki” - argumentuje Dębski we wstępie na stronie 17), o czym będzie dalej, ale nie można zarzucić autorowi jakichkolwiek usterek merytorycznych w realizacji tego opracowania. Książka Nowoczesność, rozrywka, propaganda. Historia kina we Wrocławiu w latach 1919-1945 jest bowiem przemyślanym i podbudowanym faktami projektem wydawniczym o charakterze naukowym.

Jestem przekonana, iż będzie to ważna książka zarówno dla Polaków, jak i dla Niemców, którzy po opuszczeniu miasta, jak już zostało wspomniane, przez dziesiątki lat albo nie chcieli, albo nie mogli prowadzić własnych projektów badawczych. Polakom, a zwłaszcza "powojennym wrocławianom" Andrzej Dębski podarował tą monografią (opisującą życie filmowe w ich mieście do 1945 roku) kolejny prezent. Pierwszym była książka Historia kina we Wrocławiu w latach 1896-1918)[5]. Tym razem czytelnik otrzymuje nie tylko opis wrocławskich kin epoki wilhelmińskiej, ale ich dalsze pogłębione o nowe zjawiska dzieje, aż po działalność z piętnem propagandowym Trzeciej Rzeszy w tle i kres Breslau. Przedstawione fakty zostały opatrzone subiektywnymi przemyśleniami, co nadało pracy osobisty ton, oraz tekstami „z epoki” przetłumaczonymi z niemieckiego i podanymi w formie kapitalnie pasujących do treści danego wywodu cytatów. Warto dodać, że jeśli chcielibyśmy wymienić książki naukowe poświęcone podobnej

[5] Przytoczona książka została wydana we Wrocławiu w 2009 roku. Powstała na podstawie doktoratu Andrzeja Dębskiego obronionego rok wcześniej w Centrum Studiów Niemieckich i Europejskich im. Willy'ego Brandta Uniwersytetu Wrocławskiego. W ostatniej dekadzie Dębski kierował projektem „Historia kina na Dolnym Śląsku do 1945 roku” w Centrum im. Willy'ego Brandta Uniwersytetu Wrocławskiego. Opublikował kilka ważnych artykułów powiązanych tematycznie z kinem we Wrocławiu i na Dolnym Śląsku do 1945 roku oraz dotyczących w ogóle początków kina w perspektywie sztuki widowiskowej. Jest też pomysłodawcą, współredaktorem (obok Martina Loiperdingera) i tłumaczem zbioru tekstów współczesnych niemieckich badaczy zajmujących się niemym kinem pt. KINtop. Antologia wczesnego kina, część 1 i 2, Wrocław 2016. 
problematyce, czyli dotyczącej historii instytucji kinematograficznych i kultury filmowej w dużych miastach niemieckich i polskich, tych prac nie byłoby wiele, a poza tym żadne miasto nie ma tak dokładnego opracowania, jeśli chodzi o dane statystyczne[6].

Autorowi udało się w sposób ciekawy i przyjemny w czytaniu połączyć „ciężkie” fakty z jakąś ożywczą energią własnych przemyśleń i komentarzy, ale i wtrąceń, anegdot, dopowiedzeń z materiałów prasowych, które czynią książkę ważką, syntetyczną, jeśli chodzi o dane liczbowe - fundamentalną. Przy okazji pozwolę sobie zauważyć, że autora cechuje rzadka zdolność skupiania się na meritum, wierność własnej koncepcji książki, dar pomijania błahostek i klarowny język wykładu przez kolejne chronologicznie etapy rozwoju kina we Wrocławiu, aż do zmierzchu wraz z klęską Niemiec w 1945 roku. Dzięki tym zaletom Andrzeja Dębskiego (z książki jawi się on jako erudyta, racjonalista, ale też mól książkowy i badacz maksymalista) - pomimo że jego praca zawiera ogromną liczbę krótszych i dłuższych cytatów, powołań i przypisów zbliżonych tematycznie (dotyczących kolejnych kin opisywanych według podobnego klucza) - nie nuży, nie jest monotonna. Notabene, wszystkie uwagi krytyczne lub objaśniające do cytatów podane zostały trybem syntetycznego komentarza bądź włączenia wątków kontekstowych, dygresji etc.

Można odnieść wrażenie, że Dębski, nawet zamykając opracowanie, dodajmy: perfekcyjnie przedstawiające to, co w branży kinowej Wrocławia działo się do zakończenia II wojny światowej[7], ciągle czuje niedosyt z powodu niewyczerpania tematu. Wyjawia więc przed czytelnikiem, czego nie opisał, choć być może powinien, próbuje się zresztą z tego tłumaczyć, tak więc owo "nienasycenie” twórcze bardzo trafnie oddaje osobowość autora. We „Wstępie” i „Zakończeniu” zatem, choć w kilku innych miejscach monografii również ma to miejsce, Andrzej Dębski dzieli się z czytelnikami swoimi przemyśleniami o wpływie

[6] Wymieniam tylko najważniejsze polskie wydawnictwa naukowe, które ze względów geopolitycznych ujmują w treści tematykę kinematografii niemieckiej. Są to między innymi: K. Kluczwajd, Toruńskie teatry świetlne, czyli kina, wytwórczość filmowa i miejscowe gwiazdy 1896-1939. O kulturze czasu wolnego dawnych torunian, Toruń 2015; M. Andrzejewski, $Z$ dziejów kina w Gdańsku w latach 1896-1945, Gdańsk 2013; M. Guzek, Filmowa Bydgoszcz 1896-1939, Toruń 2004; U. Biel, Śląskie kina między wojnami czyli przyjemność upolityczniona, Katowice 2002; M. Hendrykowska, M. Hendrykowski, Film w Poznaniu $i$ Wielkopolsce 1896-1996, Poznań 1996; H. Krajewska, Życie filmowe $w$ Łodzi w latach 1896-1939, Warszawa, Łódź 1992; seria zbiorówek „Z Dziejów X Muzy na Górnym Śląsku” pod red. A. Gwoździa (wydawana w Katowicach od 1996 roku). Można się też spodziewać, iż w najbliższym czasie o kinową historię upomni się Szczecin, Olsztyn i Opole, w 1939 roku miasta ok. 50-tysięczne. Być może warto dodać informacje o kilku polskich opracowaniach dotyczących miast galicyjskich (należących do zakończenia Wielkiej Wojny do Austro-Węgier), by wymienić Lwów i Tarnów: B. Gierszewska, Kino i film we Lwowie do 1939 roku, Kielce 2006; R. Włodek, 100 lat „Marzenia”. Historia kina w Tarnowie, Tarnów 2013. Ponadto do cennych publikacji dokumentujących historię kina niemieckiego z polskiej perspektywy należy odnotować artykuły problemowe publikowane w czasopismach naukowych lub popularyzujących wiedzę, w tym między innymi M. Andrzejewskiego, Rozwój kina $w$ Elblagu $w$ latach 1918-1945, „Rocznik Elbląski” 2006, t. 20, s. 7-13.

[7] Jeśli chodzi o dane biograficzne „kiniarzy”, w wielu wypadkach autor „dopisał” ich powojenne losy. 
nowych koncepcji historiograficznych na przyszłe badania nad kinem Wrocławia okresu weimarskiego i Trzeciej Rzeszy, choć te refleksje mogą być inspirujące w ogóle dla badaczy kinematografii okresu niemego i dźwiękowego na całym świecie. W pewnym momencie dokonuje jednak nagłej wolty, którą można też nazwać suspensem „Epilogu”, a na pewno wiele dobrego mówiącym o autorze, postscriptum książki. Otóż, przywołując pamięcią pierwszą dekadę kinowego Wrocławia po zakończeniu II wojny światowej, informując o zmianie nazw czterech kin, które przetrwały ponury czas nazizmu (Warszawa to dawny Palast-Theater; Polonia to Odertor-Lichtspiele; Pionier zainstalowano w budynku Titania-Theater; Capitol stał się kinem Śląsk), o pierwszych filmach (jak Majdanek - cmentarzysko Europy), wojennych radzieckich produkcjach (Trzewiczki) i tych przedwojennych (Strachy, Znachor, ale też Wielki walc i $W$ cieniu krzyża) granych z myślą o Polakach, ale oglądanych również przez Niemców, którzy jeszcze miasta nie opuścili, Dębski umieszcza opowieść o dwóch różnych „magnatach” niemieckiego kina we Wrocławiu, którzy po wojnie z powodzeniem kontynuowali kariery na Zachodzie. Sądzę, że to właśnie ta historia Erwina Hirschberga i Hellmuta Anlaufa, oparta na faktach i doskonale przekazana, dobitnie potwierdza dojrzałość badawczą i wyjątkową osobowość Andrzeja Dębskiego. Chodzi o, z pozoru banalną, fotografię wykonaną przez ulicznego fachowca (może to był lwowiak?) z zastosowaniem szablonowej ścianki $\mathrm{z}$ wycięciem na tors modela i opatrzonej napisem „Nie zapomnij mnie", która nadała książce subtelności i dramaturgii zarazem. Zrobił ją sobie E. Hirschberg w 1954 roku, kiedy jedyny raz od momentu „przeprowadzki” w 1933 roku do Holandii, pobycie w Auschwitz (gdzie zagazowano jego brata) incognito odwiedził Wrocław. To zdjęcie jest przysłowiową „wisienką na torcie”, niespodzianką z aurą, jaką udało się autorowi zrobić czytelnikowi. Należy pogratulować Dębskiemu pomysłowości, talentu, pasji i fartu (takie zdjęcie!), które to cechy w jego dwuczęściowej monografii Nowoczesność, rozrywka, propaganda. Historia kina we Wrocławiu w latach 1919-1945 po prostu widać. A jeśli chodzi o samą książkę, nie ma cienia wątpliwości, że zostanie bardzo dobrze zrozumiana i zapamiętana zarówno przez polskich, jak i niemieckich odbiorców.

Pozornie niewiele miejsca poświęca autor omówieniu kultury filmowej we Wrocławiu, w moim odczuciu sprawie istotnej, gdyż niewątpliwie inspirującej bardziej wymagającą publiczność do poznawania ambitniejszej oferty kinowej, czyli wykraczającej poza rolę transmisji nowoczesności, rozrywki i propagandy. I z pewnością autor zdawał sobie sprawę, że wraz z rozwojem kinematografii zmieniała się świadomość filmowa widza i następowały przeobrażenia w widzeniu kina na scenie komunikacyjnej tak przez podmioty ją tworzące, jak i przez jej uczestników w roli odbiorcy. A jednak, z jakichś powodów, Dębski nie wprowadził sfery kultury filmowej w tok pierwszoplanowych rozważań, pozostawiając ten temat w obszarze retrospekcji. Taki zabieg - skądinąd świadczący o zuchwałości autora, ale i przekonaniu o inteligencji osób, 
które zechcą przeczytać jego książkę - pozostawia bowiem odbiorcę z pytaniami „W głowie” lub zmusza go wręcz do szukania odpowiedzi implicytnie, do stawiania hipotez czy konstatacji po swojemu. $\mathrm{Na}$ szczęście kultura filmowa w fundamentalnej pracy Andrzeja Dębskiego o historii wrocławskiego kina jest obecna i broni się sama, choć czytelnik musi włożyć nieco wysiłku intelektualnego w lekturę i powinien być uważny, aby sobie dopowiedzieć to wszystko, czego autor nie wyłożył „wprost”. Preferuje on jednak inne tezy dociekań badawczych, w których kultura filmowa została jedynie zasygnalizowana, choć w tle jest stale obecna i ważna. Według tez Dębskiego rolą kina we wrocławskim spektrum było zapewnienie publiczności przyjemności, relaksu, zabawy, odskoczni od codzienności. Ich właściciele, zarówno w okresie weimarskim, jak i Trzeciej Rzeszy podlegali prawu podaży i popytu, zatem w interesie kin była troska o repertuar, który dawał zysk. Filmy wysoko wartościowe artystycznie, o charakterze edukacyjnym, choć zwolnione od podatku lub dostępne ze zniżką, i tak często przegrywały z komercyjną fabułą, gdyż publiczność wolała zapłacić za farsę, dramat czy muzyczną komedyjkę. Rozumiem autora, jakkolwiek trudno mi się zgodzić z jego tokiem myślenia, gdyż zagadnienie jest bardziej złożone. Opisując stan faktyczny funkcjonowania kin i wręcz udowadniając szczegółowymi zestawieniami statystycznymi, że wrocławianie (i nie tylko oni) kochali szmirę, więc ją dostawali, Dębski potwierdza znany fakt.

Andrzej Dębski bezsprzecznie akceptuje socjologiczne i kulturowe mierniki, jak najbardziej wykorzystuje je we własnych uzasadnieniach i sytuuje kina w przedmiocie kultury popularnej, jakkolwiek chętniej nazywa ją li tylko „rozrywką”, a nie na przykład „kulturą masową”. Bliższe są mu jednak badania ilościowe, więc danych liczbowych według obliczeń własnych i przejętych z innych zasobów jest w książce ogrom i dają autorowi chyba najwięcej satysfakcji. Z pewnością zebranie tych danych było to zadanie bardzo trudne - w moim odczuciu - nie do ogarnięcia. Pewnie powiodło się wszystko według zamierzonego planu tylko dlatego, że Andrzej Dębski postawił na zawodowstwo: jest nie tylko kulturo- i filmoznawcą, ale też ekonomistą, którą to profesję od wielu lat wykorzystuje z powodzeniem do badań ilościowych w zakresie wczesnego kina. Tym razem umiejętność operowania liczbami dała rezultaty jakościowe. Dzięki metodom statystycznym otrzymaliśmy nie tylko szczegółowe dane dotyczące funkcjonowania kin w Breslau, ale wszechstronne analizy potwierdzające mechanizmy różnych motywacji indywidualnego i wspólnotowego uczestnictwa w seansach kinowych mieszkańców Wrocławia w badanym okresie, w innych opracowaniach dotyczących kina do 1945 roku na ziemiach polskich potraktowane fragmentarycznie i mało dokładnie. Można powiedzieć, że po raz pierwszy otrzymaliśmy wskazówki, jak sobie radzić z materialnością i ekonomikami kin.

Autor wielokrotnie podkreślał w książce możliwości, jakie daje metoda POPSTAT (jak pisze Dębski, „służąca badaniu historycznych 
preferencji publiczności kinowej")[8]. Nie do końca podzielam taki totalny respekt autora recenzowanego dzieła dla wagi obliczeń nakierowanych na odkrywanie filmowych gustów widzów i badanie polityki repertuarowej wrocławskich „kiniarzy”, ale Dębski uznał je za odkrywcze. Tak więc obydwa te kryteria, zdaniem Dębskiego, to najważniejsze wyznaczniki służące analizie widowni i jej wpływu na kształt miejscowych kin. Oczywiście nie kwestionuję ich, wręcz przeciwnie, przyglądam się wynikom z ciekawością, ale jestem sceptyczna wobec entuzjazmu autora, iż dzięki nim można opisać obiektywniej (lepiej?) złożone i rozlegle zjawisko, jakim były wówczas wybory filmów i kin, niż posiłkując się metodami, technikami i narzędziami badawczymi wypracowanymi przez naukowców zajmujących się kinem w szeroko rozumianej komunikacji kulturowej. Wydaje mi się, że takie badania mogą co najwyżej potwierdzić wnioski, które jakby nasuwają się same. Przykładowo odniosę się do postępującego procesu koncentracji w przemyśle filmowym w Trzeciej Rzeszy (zresztą podobne tendencje dotyczyły dużo wcześniej monopolizacji kina przez amerykańskie wytwórnie i biura wynajmu), który mocno hamował istnienie niezależnych kin. Jak wiadomo, właściciele mieli niewielki wpływ na repertuar swoich przedsiębiorstw (chyba że na variétés), to jakie znaczenie ma, że jeden widz wybrał w Walhalla-Theater farsę, a inny w Tivoli film sensacyjny? W moim przekonaniu nie ma żadnego, chodziło po prostu o to, aby kupowali bilety i mieli stały nawyk uczęszczania do kina. Jak pisała Kłoskowska: „W świecie filmu machina konkurencji operująca aparatem finansowych nacisków w ciągu kilkudziesięciu lat skutecznie eliminowała rozwój przejawów nokonformizmu, samodzielności i oryginalności”[9].

Recenzowana książka to rodzaj nietypowego kompendium o luźnej strukturze, ale spajającej historiografię, kronikę wydarzeń, rozrywkę, kulturę i politykę, z ekonomiką działających we Wrocławiu przedsiębiorstw kinowych. A właściwie to dwie grube książki formatu A5 (obydwa tomy liczą w sumie prawie 900 stron). Jak deklaruje autor, jego „Zamiarem było nie tylko przybliżenie lokalnej kultury filmowej, ale i tych aspektów kina w Republice Weimarskiej i Trzeciej Rzeszy, które rzadko są dostrzegane w badaniach filmoznawczych" (cz. I, s. 17). Tytułowe klucze: „nowoczesność”, „rozrywka” i „propaganda” kierują uwagę czytelnika na pola zagadnień - zdaniem Dębskiego i jego naukowych mentorów - istotnych dla kina w tym okresie. Jak już wspomniałam, z pewnością autor celowo pominął w nazwie książki paradygmat kulturowy, na mój ogląd mocno podkreślany przez niego w komentarzach do materiału faktograficznego oraz stale obecny we fragmentach cytowanych tekstów z prasy lokalnej i filmowej o zasięgu ogólnokrajowym i miejscowym. Czytając, parę razy miałam wrażenie, że autor jednak wychodzi poza kanoniczne dla niego teksty Josepha Garncarza i André Gaudreaulta oraz „twarde dane” liczbowe, naturalnie wpisując fakty 
kulturowe w przestrzeń wrocławskich kin. Sądzę, że inaczej się po prostu nie da, gdyż informacje o otwarciach, przebudowach, repertuarach, sprzedaży biletów do kin gromadzone są w określonym celu. Zarówno badaczom „kina atrakcji”, jak i tym, którzy optują za włączeniem kina w awans kulturowy „nowej publiczności”, w gruncie rzeczy chodzi o to samo: o sprostowanie wielu mitów, błędnego rozpoznania kwestii dotyczących wagi i miejsca widza przed ekranem, gdyż prawda - jak to bywa, leży pośrodku. Przekonywanie do swoich poglądów nie jest potrzebne, pożądana jest natomiast wzajemna i pogłębiona dyskusja, która mogłaby zaowocować odkryciem, że tak naprawdę nie ma konfliktu, badamy to samo zjawisko, ale w zależności od doboru argumentów (a ten zawsze jest subiektywny), interpretacji faktów, dochodzimy (czasami) do różnych uogólnień. Głos J. Garncarza, uznany przez Dębskiego za "programowy” dla jego kompendium o wrocławskiej widowni (cyt.): „Dopiero kiedy historiograf za kryterium wyboru filmów i gwiazd uzna nie własne preferencje, lecz ówczesnej publiczności, poznamy popularną weimarską kulturę filmową" (cz. 1, s. 18)[10], dla mnie jest jakby potwierdzeniem tego, co, jak mi się wydaje, już wiem. O ile zatem doceniam zbiór informacji o historii i mechanizmach funkcjonowania miejscowych kin w świetle dokumentów i perspektywie autora, uważam za nie do przecenienia przybliżenie sylwetek wrocławskich „kiniarzy” i staranność opisania (o ile było to możliwe) ich powojennych losów, o tyle mam wątpliwości, czy rzeczywiście wiele zmieniło rozpoznanie wykonane metodą POPSTAT. Tym bardziej, że badanie wymagało ogromu pracy i środków, a wszystko po to, aby się przekonać - oczywiście trywializuję problem, ale coś w tym jest - jaką szmirę wybierali wrocławianie spośród przygotowanego dla nich repertuaru (na przykład $\mathrm{z}$ arcydziełem kina niemego włącznie). Zresztą, Dębski sam cytuje opinię, że tak naprawdę nie miało większego znaczenia, co publiczność postanowi, byleby chodziła do kin. Jako głos drugiej strony pozwolę sobie zacytować Małgorzatę Hendrykowską, która napisała o kinie, iż „przyszło do widza bez tych wszystkich obciążeń i zaproponowało mu «prawdziwe» $\mathrm{i}$ «autentyczne», aktualne i wspólne uczestnictwo we wszystkich najżywotniejszych problemach współczesności”[11]. Autorka Śladami tamtych cieni opisuje nie tylko przyjemność chodzenia do kina, spotykania się, aby wspólnie przeżywać emocje, ale rodzące się wraz $\mathrm{z}$ dostępem do kinematografu potrzeby wyższego rzędu, natomiast dane repertuarowe interpretuje intuicyjnie. $Z$ własnego doświadczenia badań nad filmowym Lwowem pozwolę sobie dopowiedzieć, że chyba nie może być jakiegoś dużego błędu w skalkulowaniu, jakie filmy preferowała młodzież, kucharka, robotnik, nauczyciel, wojskowy, studentka filozofii, czyli osądu o tym, co było grane, a co było oglądane, by użyć „wytrychu” badawczego Andrzeja Dębskiego. To oczywiście

[10] J. Garncarz, Warum kennen Filmhistoriker viele Weimarer Topstars nicht mehr? Überlegungen am Beispiel Claire Rommer, „montage/av” 1997, Nr. 2, s. 89-91. Cyt. za: A. Dąbski, Nowoczesność, cz. 1, s. 18.
[11] M. Hendrykowska, Śladami tamtych cieni, Poznań 1993, s. 102. 
tylko moje dywagacje, które nie mają przełożenia na bardzo wysoką wartość książki Dębskiego w mojej ocenie. Wiem też, że powróciła do łask w badaniach humanistycznych statystyka i jest rozwijana dzięki możliwościom, jakie dają nowe technologie. Przyznaję, Dębski wykonał to zadanie z dużą starannością, a czy te wyniki zmienią ogląd filmowego Wrocławia w badanym okresie, czy odwrócą historię wczesnego kina w Europie Środkowej, zobaczymy. W każdym razie Dębskiego pociąga w badaniach nad wczesnym kinem idea niemieckiego uczonego Josepha Garncarza, który jako jeden z pierwszych wykorzystał w badaniach nad preferencjami publiczności kinowej metodę POPSTAT, a poza tym zaproponował rewizję definiowania „popularności” z kulturowej na „empiryczno-porównawczą”, podzielaną przez autora recenzowanej książki. „Wychodząc z tego założenia [chodzi o wskazówki Garncarza], ustaliłem, jakie filmy najchętniej oglądali wrocławianie, a także starałem się dociec, co mogło im się w nich podobać, ewentualnie dlaczego" (cz. I, s. 18) - pisze Dębski.

Książka nie ma prostej i jednakowej budowy, jakkolwiek autor od początku do końca nie rezygnuje z niezależnego wyboru materiału do kompendium i dążenia do sumiennej, osobistej oceny faktów, które poddaje analizie. Nie ma też w publikacji żadnego „niedbalstwa”, moja uwaga dotyczy raczej niejednolitości w sposobie pisania o wrocławskich kinach z powodu bardzo różnej ilości materiału i odmiennych wyborów autora co do jego przedstawienia, podsumowania. Najlepiej są skomponowane rozdziały wstępne i refleksje końcowe, które są skróconym opisem stanu badań, zawartości treściowej i analizą danych statystycznych.

Układ każdej części (książka składa się z dwóch tomów) jest dostosowany do jej zawartości tematycznej. W części „Kina” podstawą uporządkowania materiału była tak zwana „Kronika: otwarcia, modernizacje, zamknięcia" w poszczególnych latach. To krótsze lub bardziej obszerne dane identyfikacyjne kin, czasami z fotografiami anonsów otwarcia i żywymi fragmentami głosów prasowych. Można sądzić na pierwszy rzut oka, że będą to podobne, więc monotonne opisy, ale tak nie jest, przeciwnie, to bardzo atrakcyjne źródło informacji nie tylko dla filmoznawców i kulturoznawców, ale dla architektów, badaczy przestrzeni miejskiej i wszystkich miłośników Wrocławia. Wartością „Kronik” jest bardzo drobiazgowa faktografia z opisem bibliograficznym w przypisie. Autor wydzielił trzy okresy w historii wrocławskich kin i opatrzył je nazwą. I tak lata 1919-1925 to: „Powojenny boom i okres stabilizacji”, lata 1926-1932 otrzymały dopisek: „Inflacja miejsc i czasy kryzysu”, czasy Trzeciej Rzeszy 1933-1945 to okres: „Pod rządami narodowych socjalistów”. Po „Kronikach” każdego rozdziału pojawia się podrozdział "Statystyka” oraz - dla mnie najciekawszy - gęsty od szczegółów dział „Właściciele”, który jest jakby zwiastunem treści drugiej części kompendium.

Na tom „W kinach” składają się programy kin, listy najpopularniejszych filmów we Wrocławiu oraz znakomity „Epilog”, który cytowa- 
łam wcześniej. W programach autor wydzielił dwa okresy: weimarski oraz Trzeciej Rzeszy. Pierwszy, oprócz przedstawienia poszczególnych sezonów kinowych i rankingów filmowych w różnych kategoriach, został poszerzony o podrozdział „Wrocławskie kluby filmowe” o charakterze raczej sygnalnym. Należy odnotować, że znalazł się w nim mało znany u nas tekst Siegfrieda Kracauera (w tłumaczeniu T. Gabisia) pt. Dzisiejszy film i jego publiczność[12] z towarzyszącą analizą Dębskiego.

Domeną zainteresowań Andrzeja Dębskiego w pierwszej części monografii było (cyt. s. 14) „uporządkowanie faktów w porządku diachronicznym w podziale na następujące lata. Taki układ wydawał mi się właściwszy dla uwidocznienia dynamiki zachodzących procesów” - wyjaśnia autor. Natomiast w części drugiej, zatytułowanej „W kinach", autor recenzowanej pracy bada, analizuje i komentuje "ofertę programową kin i preferencje filmowe widzów” (s. 15). Opierając się przede wszystkim na tak zwanych „twardych danych” wrocławskich kin dostępnych na łamach „Breslauer Neueste Nachrichten”, utworzył listy najpopularniejszych filmów granych we Wrocławiu w wybranych sezonach: 1926/1927, 1929/1930, 1930/1931, 1938, czyli nie wszystkich, i porównał je z podobnymi rankingami dotyczącymi popularności konkretnych filmów w całych Niemczech w latach 1925-1944. Zostały one utworzone na podstawie ankiet „Film-Kuriera” oraz źródeł archiwalnych (między innymi dot. Ufy) i powojennych opracowań poświęconych kinematografii Trzeciej Rzeszy i weimarskiej[13].

Książkę dopełnia bogaty materiał ilustracyjny. Wkładka z planami i zdjęciami kin to, poza wszystkim, przeżycie estetyczne. Do opracowania włączono aż 36 tabel z bardzo drobiazgowymi informacjami i wyliczeniami statystycznymi dotyczącymi funkcjonowania wrocławskich kin do 1945 roku. Zebrane i podane w sposób przemyślany i wymowny potwierdzają ogrom pracy Andrzeja Dębskiego i są atrakcyjne poznawczo. Chyba nikt w Polsce ani w Niemczech nie przebadał tak dokładnie kin w jednym mieście, porównując je pod kątem ekonomicznym do podobnych przedsiębiorstw, jak również nie opisał rzeczywistych preferencji widzów. Jak przystało na wzorcowe opracowanie naukowe o charakterze źródłowym, również aparat naukowy został dopracowany pod każdym względem. Dzieło Dębskiego dopełnia szczegółowa informacja o wykorzystanych źródłach, gazetach i periodykach oraz opracowaniach. Dołączono indeks filmów i indeks osób, spisy tabel i ilustracji (z podaniem podpisu i źródła)

Reasumując: Andrzej Dębski napisał bardzo dobrą książkę, w której historia wrocławskiego życia filmowego do 1945 roku uzmysłowiła nam, jak ważne stały się kina dla „nowej publiczności” u progu XX stulecia. Autor pewnie wolałby, abym napisała, że ważna była publicz-

[12] S. Kracauer, Der heutige Film und sein Publikum, „Frankfurter Zeitung” 1928, 30.11 - 1. 12.; przedruk: „Breslauer Volksbuhne”; cyt. za: A. Dębski, Nowoczesność, cZ. II, s. 206.
[13] Dębski powołuje się przede wszystkim na wyliczenia zawarte w następujących publikacjach: M. Spieker, Hollywod unterm Hollywood unterm Hakenkreuz, Trirer 1999; B. Drewniak, Teatr i film Trzeciej Rzeszy, Gdańsk 2011. 
ność, która czerpała przyjemność ze stałego uczestnictwa w seansach filmowych. Taka sytuacja skutkowała pokaźnymi zyskami zarówno dla organizatorów przedsiębiorstw kinematograficznych, jak i miasta. Z kolei w okresie Trzeciej Rzeszy kina, oprócz tradycyjnych usług na rzecz mieszkańców, odegrały (z przyzwoleniem „kiniarzy” bądź z powodu zwyczajnej bierności wobec władzy) istotną rolę w przebudowywaniu świadomości społecznej ludności cywilnej oraz wojskowych. Powtórzę słowo „napisał”, gdyż to nie jest li tylko zbiór dokumentów archiwalnych, prasowych i innych zebranych i ułożonych przez autora, ale z ogromną znajomością rzeczy usystematyzowany i obudowany „wstępniakami”, „uwagami końcowymi” i wszechobecnymi w całej pracy komentarzami, podpowiedziami odautorskimi na najwyższym poziomie.

Opisanie jakże bogatej przeszłości (od połowy lat trzydziestych coraz bardziej ponurej) filmowego Wrocławia z perspektywy nie tylko wnikliwego badacza nowoczesności, ale i niestrudzonego pasjonata kina, na dodatek $\mathrm{z}$ trudną do opanowania słabością do drobiazgu, to rzecz dużego kalibru, wymagająca ogromnego doświadczenia i warsztatu naukowego, nie wspominając o naturalnej - w przypadku tej książki - konieczności przekładu z niemieckiego na polski zdecydowanie przeważającej części materiałów archiwalnych, prasowych i innych drukowanych. Z tysięcy (chyba dziesiątków tysięcy) faktów - okruchów minionego czasu zamkniętych w archiwach, wspomnieniach ludzi, inseratach, notkach, recenzjach prasowych, podpisach pod ilustracjami etc. - Andrzej Dębski zrekonstruował kronikę funkcjonowania wrocławskich kin, zapoznał nas z właścicielami i ich kreatywnością $\mathrm{w}$ prowadzeniu swoich przedsiębiorstw w taki sposób, aby były konkurencyjne wobec innych, zyskiwały na popularności, przyciągały stałą publiczność. Dużo miejsca w części I recenzowanej pracy (pt. Kina) zajęło przedstawienie architektów - budowniczych miejscowych kin oraz wielowymiarowe opisanie i pokazanie (plany, fasady, wnętrza, detale) architektury i wyposażenia poszczególnych kin, włączając modernizacje, rewitalizacje i pomniejsze remonty. Zdjęć kin wrocławskich, które zostały zaprezentowane w publikacji, trudno Dębskiemu nie zazdrościć, zresztą podobnie jak całego materiału ikonograficznego. Może brakuje mi tylko jednego ujęcia: utrwalenia ludzi na widowni, przed kinem, przyglądającym się witrynom, słupom reklamowym etc.

Monografia, kompendium, repetytorium - po prostu wspaniała naukowa książka autorstwa Andrzeja Dębskiego to... swoisty pomnik wystawiony publiczności, właścicielom i obsłudze wrocławskich kin przez intelektualne siły niemieckie i polskie obecnego stulecia.

Andrzejewski M., Rozwój kina w Elbląu w latach 1918-1945, „Rocznik Elbląski” 2006, t. 20, s. 7-13

Andrzejewski M., Z dziejów kina w Gdańsku w latach 1896-1945, Gdańsk 2013

Biel U., Śląskie kina między wojnami, czyli przyjemność upolityczniona, Katowice 2002 
Dębski A., KINtop. Antologia wczesnego kina, część 1 i 2, Wrocław 2016

Drewniak B., Teatr i film Trzeciej Rzeszy, Gdańsk 2011

Garncarz J., Warum kennen Filmhistoriker viele Weimarer Topstars nicht mehr? Überlegungen am Beispiel Claire Rommer, „montage/av” 1997, nr 2, s. 89-91

Gierszewska B., Kino i film we Lwowie do 1939 roku, Kielce 2006

Guzek M., Filmowa Bydgoszcz 1896-1939, Toruń 2004

Hendrykowska M., Śladami tamtych cieni, Poznań 1993

Hendrykowska M., Hendrykowski M., Film w Poznaniu i Wielkopolsce 1896-1996, Poznań 1996

Kluczwajd K., Toruńskie teatry świetlne, czyli kina, wytwórczość filmowa i miejscowe gwiazdy 1896-1939. O kulturze czasu wolnego dawnych torunian, Toruń 2015

Kłoskowska A., Kultura masowa, Warszawa 1964

Kracauer S., Der heutige Film und sein Publikum, „Frankfurter Zeitung” 1928, 30.11-1 12

Krajewska H., Życie filmowe w Łodzi w latach 1896-1939, Warszawa-Łódź 1992

Morin E., Duch czasu, Warszawa 1965

Morin E., Kino i wyobraźnia, Warszawa 1958

Schopenhauer A., W poszukiwaniu mądrości życia. Parerga i paralipomena, t. 1, Warszawa 2002

Spieker M., Hollywod unterm Hollywood unterm Hakenkreuz, Trirer 1999

Włodek R., 100 lat „Marzenia”. Historia kina w Tarnowie, Tarnów 2013

Z dziejów X muzy na Górnym Śląsku, red. A. Gwoźdź, Katowice 1996 [+ dalsze tomy] 